\title{
Óbito fetal no Hospital Universitário Regional do Norte do Paraná de 1997 a 2000'1
}

\section{Fetal deaths at Hospital Universitário Regional do Norte do Paraná from 1997 to 2000}

\author{
Denise Cavenaghi Prete ${ }^{2}$ \\ Orientador: Prof. Dr. Fernando Mangieri Sobrinho
}

Fundamentos: O óbito fetal não é uma entidade rara. Fatores epidemiológicos, fatores de risco e sua prevalência em diversas populações, ao serem estudados podem incrementar a assistência pré-natal, obstétrica e neonatal.

Objetivos: Conhecer a freqüência, analisar e classificar os óbitos fetais que ocorreram no Hospital Universitário do Norte do Paraná no período de 4 (quatro) anos, de 1997 a 2000. Verificar aspectos epidemiológicos e métodos de investigação dos óbitos fetais e comparar dados com a literatura.

Métodos: Neste estudo descritivo, todos os casos de óbito fetal do HURNP, no período de 4 anos (de 1997 a 2000), foram revistos retrospectivamente. Os dados foram coletados dos prontuários médicos e submetidos a análise estatística pelo programa EPI INFO.

Resultados: Foram identificados 97 casos de óbito fetal no período estudado no HURNP, com idade gestacional de vinte semanas ou mais, e peso fetal maior ou igual a 500 gramas. A maior proporção dos casos deu entrada no Pronto-Socorro em óbito fetal (73,4\%), e em $26,6 \%$ dos casos o óbito ocorreu no período de internamento para tratamento ou investigação. Primigestas $(36,6 \%)$ e secundigestas $(21,9 \%)$ predominaram. A idade materna variou de 14 a 44 anos, com média de 31,88. Faixas etárias mais jovens predominaram. Movimentação fetal diminuída ou ausente (22,2\% e 15,6\%) e dor abdominal (23,3\%), foram as queixas mais frequientes. Patologias associadas a doença hipertensiva (34\%) e causas indeterminadas (32\%) foram as mais encontradas.

Conclusão: Os casos de óbito fetais no HURNP, no período estudado, indicam a predominância de patologias associadas a doença hipertensiva e casos sem patologia associada, indeterminados. A investigação diagnóstica e epidemiológica foram pouco aplicadas e merecem aprofundamento através de protocolos específicos.

\footnotetext{
Resumo de Dissertação de Mestrado em Medicina. Defendida em 09/11/2001. Universidade Estadual de Londrina.

2 deniseprete@uel.br - Rua Paranagua, 199/904 CEP 86020030 - Londrina 'PR
} 
Prete, D. C.

Prete DC. Óbito Fetal no Hospital Universitário Regional de Norte do Paraná de 1997 a 2000 [dissertação]. Londrina: Universidade Estadual de Londrina; 2001

Prete, DC, Fetal Deaths at the Universty Hospital of Northern Paraná From 1997 to 2000 [dissertation]. Londrina: State University of Londrina, 2001

\begin{abstract}
:
Fundamentals: Fetal deaths is not a rare occurrence. Epidemiological and risk factors and its prevalence in several populations, as they are studied may improve obstetrical and neonatal assistance.
\end{abstract}

Objectives: Our purpose is to know the frequency, analyze and to classify the cases of fetal deaths which have occurred at the University of Northern Paraná (HURNP) within the period of 4 (four) years, from 1997 to 2000. It is also our purpose to verify epidemiological aspects and investigation methods of fetal deaths, and compare the data with existing literature.

Methods: In the descriptive study all the occurrences of fetal deaths in the HURNP within the period of 4 (four) years were restrospectively reviewed, the data were collected from medical reports and submitted to statistical analysis by means of the EPI INFO program.

Results: 97 cases of fetal deaths were identified in the period of 4 (four) years in the HURNP, with pregnancy period of 20 (twenty) weeks or more, with fetal weight higher or equivalent to five hundred grams (500g). Most cases were registered in the emergency as fetal deaths (73.4\%) In $26.6 \%$ of cases, the death occurred within the period of confinement for treatment or investigation. The age of mothers ranged from 14 to 44 years old, being the average 31.88. Youngers mothers predominated. Diminished fetal movement or lack of movement (22.2\% and 15.6\%) and abdominal pain (23.3\%), were the most frequent complaints. Pathologies associated with hypertension diseases (34\%), and indeterminate causes (32\%), were the most frequent ones.

Conclusion: The cases of fetal deaths at the HURNP within the studied period indicate the predominance of pathologies that are associated with hypertension diseases and cases without associated pathology were undetermined. Diagnosis and epidemiological investigation were scarcely applied and deserve further studies. 